\title{
Fusarium Wilt Affecting Chickpea Crop
}

\author{
Warda Jendoubi ${ }^{1,2}$, Mariem Bouhadida ${ }^{1, *}$, Amal Boukteb ${ }^{1,3}$, Mohamed Béji ${ }^{1,3}$ \\ and Mohamed Kharrat ${ }^{1}$ \\ 1 Field Crops Laboratory, University of Carthage, INRAT, Rue Hedi Karray, 2080 Ariana, Tunisia; \\ war44da@yahoo.fr (W.J.); amal.boukteb@fst.utm.tn (A.B.); mohamed.beji21@gmail.com (M.B.); \\ kharrat.mohamed@iresa.agrinet.tn (M.K.) \\ 2 National Agronomic Institute of Tunisia, 43 Av Charles Nicolle, 1082 Tunis, Tunisia \\ 3 Faculty of Sciences of Tunis, Campus University, University of Tunis El Manar, El Manar, 1068 Tunis, Tunisia \\ * Correspondence: mariembouhadida@gmail.com; Tel.: +216-21102151 \\ Academic Editor: Yiping Qi \\ Received: 13 December 2016; Accepted: 6 March 2017; Published: 9 March 2017
}

\begin{abstract}
Chickpea (Cicer arietinum L.) contributes 18\% of the global production of grain legume and serves as an important source of dietary protein. An important decrease in cropping area and production has been recorded during the last two decades. Several biotic and abiotic constraints underlie this decrease. Despite the efforts deployed in breeding and selection of several chickpea varieties with high yield potential that are tolerant to diseases, the situation has remained the same for the last decade. Fusarium wilt caused by Fusarium oxysporum f. sp. ciceris (Foc) is the major soil-borne fungus affecting chickpeas globally. Fusarium wilt epidemics can devastate crops and cause up to $100 \%$ loss in highly infested fields and under favorable conditions. To date, eight pathogenic races of Foc (races 0, 1A, 1B/C, 2, 3, 4, 5 and 6) have been reported worldwide. The development of resistant cultivars is the most effective method to manage this disease and to contribute to stabilizing chickpea yields. Development of resistant varieties to fusarium wilt in different breeding programs is mainly based on conventional selection. This method is time-consuming and depends on inoculum load and specific environmental factors that influence disease development. The use of molecular tools offers great potential for chickpea improvement, specifically by identifying molecular markers closely linked to genes/QTLs controlling fusarium wilt.
\end{abstract}

Keywords: chickpea; fusarium wilt; molecular markers; genetic resistance; molecular assisting selection

\section{Chickpea}

Chickpea, also called garbanzo bean or Bengal gram, is a self-pollinated, annual diploid $(2 \mathrm{n}=2 \mathrm{x}=16)$ species [1] with a genome size of $738 \mathrm{Mb}$ [2], While this size is slightly larger than that of the model legume, Medicago truncacula Gaertn., (530 Mb), it is much smaller than other major legume crops such as soybean, peanut, garden pea, alfalfa, and lentil [3]. The Cicer genus belongs to the family Leguminoseae, sub-family Papilionaceae and tribe Cicereae. It is composed of 9 annual and about 34 perennial wild species. Among the 9 annual species, chickpea (C. arietinum L.) is the only cultivated species [4]. Chickpea has the ability to increase the soil fertility, particularly in dry lands, by fixing atmospheric nitrogen $(\mathrm{N})$. It is mainly used for human consumption and is an essential constituent of the Mediterranean diet and a basic food in Pakistan and India [5]. The chickpea grain international market is very active due to the crop's nutritional value. Chickpea is a good and cheap source of protein for people in developing countries (especially in South Asia), who are largely vegetarian, either by choice or because of economic reasons [6]. Chickpea is high in protein, low in fat and sodium, cholesterol free and is an excellent source of both soluble and insoluble fiber, as well as complex carbohydrates, vitamins, folate, and minerals, especially calcium, phosphorous, iron, and magnesium [7]. 
The immediate wild relatives (C. reticulatum and C. echinospermum) of chickpea are restricted to south-eastern Turkey. Domestication is thought to have happened earlier, as much as 10.5 thousand years ago, with the domestication of other crops such as wheat, barley, pea, and lentil.

There are two distinct types of cultivated chickpea: Desi and Kabuli. The Desi (microsperma) types have pink flowers anthocyanin pigmentation on stems, and a colored and thick seed coat. The Kabuli (macrosperma) types have white flowers, lack anthocyanin pigmentation on stems and have white or beige-colored seeds with a ram's head shape, a thin seed coat and a smooth seed surface [8]. The geographic distribution differs for these two types, Kabuli chickpea seeds are grown in temperate regions, whereas the Desi type is grown in the semi-arid tropics [9]. Kabuli-type chickpea is considered more economically important as it receives higher market price than Desi-type. However, most of the genomic resources have been generated for Desi-type chickpea so far [10]. The two types represent different genetic background, differing in important agronomic traits, such as disease resistance, cold tolerance and growth habit [11,12].

Chickpea is cultivated mostly in the Mediterranean basin, the Near East, Central and South Asia, East Africa, South America, North America and, more recently, in Australia. The main producers are India, Australia and Pakistan, contributing $67.32 \%, 6.19 \%$ and $5.72 \%$, respectively, to global production. Countries such as Australia, Mexico and Russia are not chickpea consumers but major world exporters [13]. The major importing countries are India and Pakistan followed by Bangladesh. In 2013, chickpea was the third grain legume in Tunisia after dry bean and peas, i.e., 6660 ha and 7840 tons, respectively. Nevertheless, chickpea production in Tunisia is not sufficient to cover the national demand, requiring $85 \%$ of the demand to be imported [13].

Fluctuations in the acreage of cultivated area of chickpea and annual production were observed this last decade (Figure 1). Average global chickpea yield improved during the past decades, increasing from $683 \mathrm{~kg} / \mathrm{ha}$ in 1990 to $966 \mathrm{~kg} / \mathrm{ha}$ in 2014 [13], but it is still considered below the yield potential of the crop. This increase is attributed to the development of new resistant varieties to biotic and abiotic stresses.

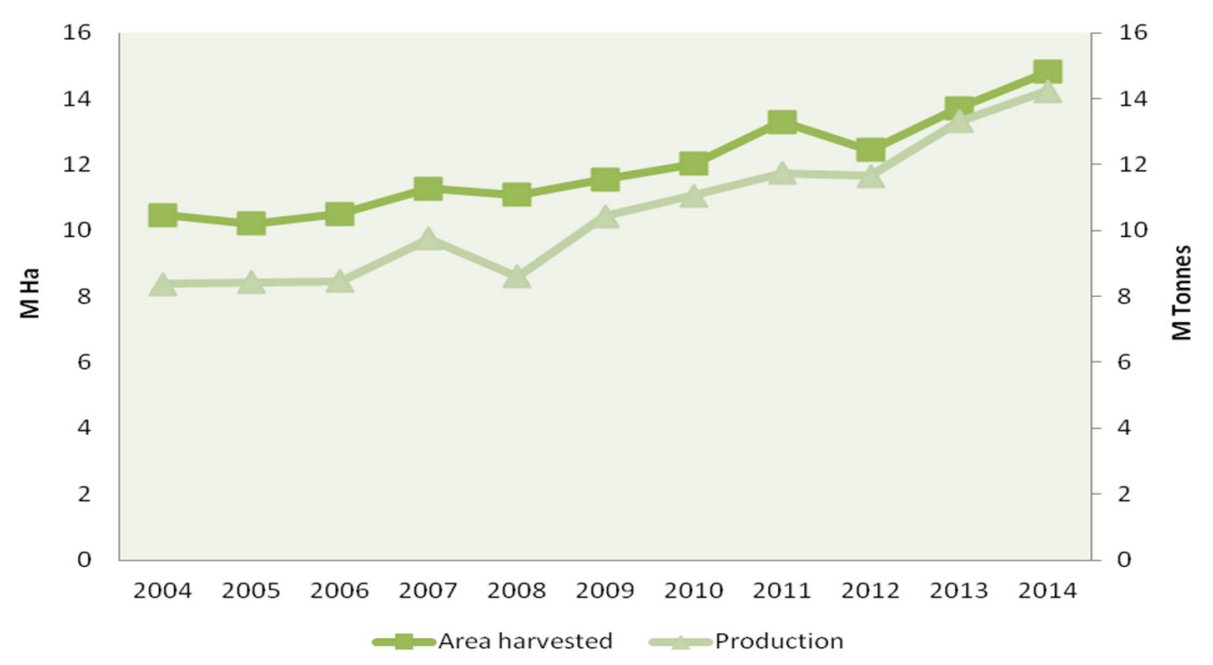

Figure 1. Cultivated area (ha) and production (tons) of chickpea in the world over the last decade.

Breeding efforts have contributed substantially to improve chickpea yield, but the lack of stable production still continues to be a major concern for the adoption of this crop by farmers [14]. One major limiting factor is susceptibility of cultivars to several biotic and abiotic stresses that adversely affect yield, particularly fungal diseases (Ascochyta blight and Fusarium wilt), pests (pod borer) and drought or cold stress. Parasitic plants could also be a serious problem in particular environments such as under Mediterranean conditions [6,14,15]. 
The development of cultivars resistant to major diseases is one of the most important objectives of chickpea breeding programs. In recent years, cultivars resistant to Ascochyta blight, Fusarium wilt and cold have been bred and released in many countries [11]. In this review, we will focus on Fusarium wilt.

\section{Fusarium Wilt}

Chickpea wilt occurs in 32 countries across 6 continents [15]. This disease was first reported in India by Butler in 1918, but its etiology was not correctly determined until 1940 by Padwick [16]. According to Haware and Nene, [17] and Halila and Strange, [18] Fusarium wilt epidemics can be devastating to individual crops and cause up to $100 \%$ loss under favorable conditions.

\section{Causal Organism}

Fusarium wilt of chickpea is caused by Fusarium oxysporum f. sp. Ciceris Schlechtend: Fr. f Sp. ciceris (Padwick) T. Matuo \& K. Satô [19-21]. On potato sucrose agar and potato dextrose agar and under near-UV light, the aerial mycelium is at first white and cottony, but later it may become cream or salmon in color or remain white [22]. Fusarium wilt of chickpea produces microconidias, macroconidias and chlamydospores. The microconidias $(2.5-4.5 \mu \mathrm{m} \times 5-11 \mu \mathrm{m})$ are oval or cylindrical, straight or curved. Macroconidias (3.5-4.5 $\mu \mathrm{m} \times 25-65 \mu \mathrm{m})$ are produced more sparsely than microconidias and usually they are three to five septate or fusoid. Chlamydospores are formed in 15-day-old cultures and infected chickpea tissues, formed singly, in pairs or in chains, and are smooth or rough-walled [12,22]. Hyphae are septate and profusely branched. The fungus can grow at temperatures of $7-35{ }^{\circ} \mathrm{C}$ and $\mathrm{pH}$ 4-9.4. Optimal conditions for mycelial growth are $25-27^{\circ} \mathrm{C}$ and $\mathrm{pH} 5.1-5.9$, depending upon strains. Optimal $\mathrm{pH}$ for sporulation is 7.1-7.9 [22].

\section{Symptoms}

Symptoms of the disease can develop at any stage of plant growth, and affected plants may be grouped in patches or appear spread across a field [23] (Figure 2).

The wilt can be observed in susceptible genotypes within 25 days after sowing in the field (designated "early wilt") [23,24]. However, symptoms are usually more visible in the early stages of flowering, 6 to 8 weeks after sowing and can also appear up to podding stage ("late wilt"). Late wilted plants exhibit drooping of the petioles, rachis and leaflets, followed by yellowing and necrosis of foliage [23]. Early wilting causes more loss than late wilting. Nevertheless, seeds from late-wilted plants are lighter, rougher and duller than those from healthy plants [25,26].

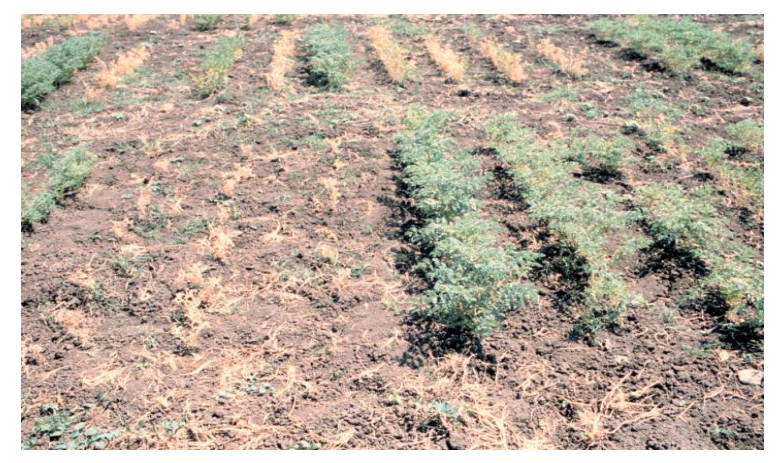

Figure 2. Chickpeas affected by Fusarium wilt in Beja-Tunisia.

\section{Disease Cycle and Epidemiology}

The fungus can be transmitted by seed and may survive in plant debris in soil. It was demonstrated that the fungus chlamydospore was found free in soil [27], in the hilum of the seed [28], in cotyledons 
and axis [29]. The primary infection is through chlamydospores or mycelia. The conidia of the fungus are short lived; however, the chlamydospores can remain viable up to the next crop season [30]. Chlamydospore formation depends on the nutrient status of the inoculum. Under field conditions, fungal inoculum may be subjected to much lower nutrient levels compared to the "well-fed" macroconidia produced on rich agar media [31]. The pathogen survives well in roots and stems, even in apparently healthy looking plants growing among diseased ones harboring sufficient fungus $[17,32]$.

The fungus remains dormant as chlamydospores in plant debris until stimulated to germinate, once carbohydrates are released from decaying plant tissue or from roots [31]. The stimulus for germination may be host or nonhost plant roots, or contact with pieces of fresh (not colonized) plant debris [33]. After the chlamydospores germinate, conidia and new chlamydospores may be formed as well as hyphae. Following germination, a thallus is produced from which conidia form in 6-8 h, and chlamydospores in 2-3 days if conditions are favorable. Invasion of the roots is followed by the penetration of the epidermal cells of the host or the non-host [34] and the development of a systemic vascular disease in host plants [35]. Penetration occurs either through wounds or directly [33]. The most common sites of direct penetration are located at or near the root tip of both taproots and lateral roots [36]. Penetration is controlled by a combination of different factors that include fungal compounds, plant surface structures, activators or inhibitors of fungal spore germination, and germ tube formation [37]. During colonization, the mycelium advances intracellularly through the root cortex until it reaches the xylem vessels and enters them through the pits. The fungus then remains exclusively within the xylem vessels (Figure 3), using them to colonize the host [38].

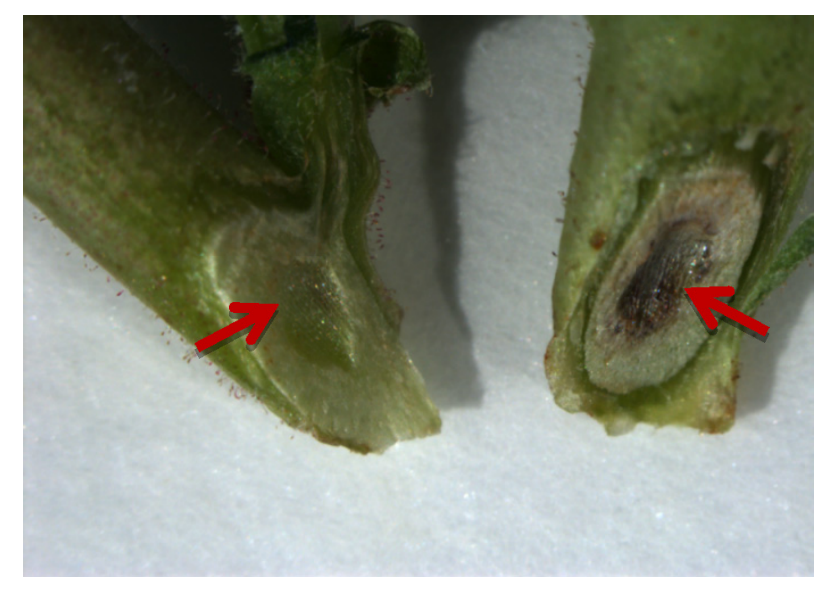

Figure 3. Stem discoloration of a chickpea plant artificially infected by Foc. Healthy plant on the left.

Wilting is most likely caused by a combination of pathogen activities. These include accumulation of fungal mycelium in the xylem and/or toxin production, host defence responses, including production of gels, gums and tyloses and vessel crushing by proliferation of adjacent parenchyma cells [39].

The pathogen can survive as mycelium and chlamydospores in seed and soil and also on infected crop residues, roots and stem tissue buried in the soil for more than 6 years, even in the absence of the host [4,12,40-42]. Infection of symptomless dicotyledonous weeds can enhance survival of the pathogen in fallow soils. Thus, infested soil is a main source of primary inoculum for the development of Fusarium wilt [24].

\section{Pathogenic and Genetic Variability in Fusarium oxysporum f. sp. ciceris}

The fungus Fusarium oxysporum f. sp. ciceris (Foc) is characterized as having pathogenic variability, i.e., consists of different pathogenic races and pathotypes. 
According to the disease symptoms induced in pathogenicity test, two pathotypes have been distinguished based on the distinct yellowing or wilting syndromes [23,32,43]. The yellowing pathotype induces progressive foliar yellowing with vascular discoloration and late plant death, while the wilting pathotype causes fast and severe chlorosis, flaccidity, vascular discoloration and early plant death [44].

Variation in the virulence among isolates of Foc has led to the designation of pathogenic races. Eight distinct physiological races have been classified for Foc, namely races $0,1 \mathrm{~A}, 1 \mathrm{~B} / \mathrm{C}, 2,3,4$, 5 and $6[43,45]$. The different races of Foc can be identified by their severity on different set of differential chickpea cultivars.

Pathogenic races of Foc differ in geographic distribution. Races $0,1 B / C, 5$, and 6 are found mainly in the Mediterranean Basin and California (USA) [23,40,44,46,47]. Race 1A has been reported in India, United States and the Mediterranean regions [20], whereas races 2 and 3 have been reported in Ethiopia, India, and Turkey $[44,48,49]$ and race 4 has been reported in Ethiopia, India and Iraq $[24,44,49]$.

Races 0 and $1 \mathrm{~B} / \mathrm{C}$ are of the yellowing pathotypes, while races $1 \mathrm{~A}$ and 2 through 6 belong to the wilting pathotypes and are economically the most damaging races [20,23]. Plants infected with races causing wilting syndrome within three to four weeks of inoculation with no visible yellowing of leaves. On the other hand, infection with races 0 and $1 \mathrm{~B} / \mathrm{C}$ leads to progressive foliar yellowing of plant leaves coupled with vascular discoloration $[43,44]$. In addition, some susceptible chickpea lines exhibit a phenomenon known as a late wilting, which is characterized by a prolonged latent period that eventually leads to $100 \%$ wilt $[12,23,45,50]$. Sharma et al. [51] reported another phenomenon called slow wilting which is characterized by a latent period, and slow disease incidence increases over time.

The identification of races of the pathogen in a given area of chickpea production is important for the breeding program as well as for the efficient use of available sources of resistance. Determination of races of this pathogen is simple but costly in time, facilities, and resources. Therefore, new methods for the rapid, efficient, reliable, and reproducible identification of the pathogen and its pathogenic races are needed. Specific primers and polymerase chain reaction (PCR) assays that identify Fusarium oxysporum f. sp. ciceris and each of the F. oxysporum f. sp. ciceris pathogenic races $0,1 \mathrm{~A}, 5$, and 6 were developed by Jimenez-Gasco et al. [47].

A study conducted by Jimenez-Fernandez et al. [19] revealed that infection of chickpea by F. redolens induces a disease syndrome similar to that caused by the yellowing pathotype of $F$. oxysporum fsp. Ciceris (Foc). Fusarium redolens is not easily differentiated from Foc using morphology-based diagnosis, and the two species cause similar symptoms on chickpea; therefore, the use of molecular protocols should help to avoid misdiagnoses of Fusarium yellows in chickpea. F. redolens was found associated with foot-rot symptoms on pea and bean [52], root rot on soybean [53], and vascular wilt on lentil [54], root rot, crown rot and spear rot in asparagus [55] and wilting in chickpea [19]. Recently F. redolens was also reported in Tunisian fields for the first time causing yellowing symptom in chickpea [56].

\section{Management}

Management of Fusarium wilt of chickpea is difficult to achieve and no single control measure is fully effective [41]. Fusarium wilt of chickpea is a monocyclic disease in which development is driven by the pathogen's primary inoculum. Therefore, management of the disease should be targeted to exclusion of the pathogen as well as by reducing the amount and/or efficiency of the initial inoculum [23]. For such a goal, measure of control should include:

\subsection{Use of Pathogen-Free Planting Material and Avoid Sowing into High Risk Soils}

Fusarium can be transmitted by infected seeds and plant debris [57,58]. Use of infected propagating material can lead to introducing the pathogen into pathogen-free soils or production areas. Therefore, the importance of checking the health of that material through certification programs, phytosanitary inspection and quarantine legislation should be considered. Proper selection of the planting site optimizes the use of F. oxysporum spp.-free planting material in non-infested soils [57]. 
Disease risk assessment based on inoculum density and disease incidence relationships would be useful. Indeed, the inoculum density in soil at planting sites could be estimated to avoid those with high risk for severe disease [57]. Recently, Jiménez-Fernández et al. [59] developed a real-time quantitative polymerase chain reaction (q-PCR) protocol that allows quantifying Foc DNA down to $1 \mathrm{pg}$ in soil as well as in root and stems of infected asymptomatic chickpea plants that may be of use for the detection and identification of the pathogen in certification programs, phytosanitary inspections and quarantine legislation. Seed-borne inoculum can be eradicated by seed dressing with Benlate [28].

\subsection{Reduction or Elimination of the Inoculum in Soil}

Soils infested with pathogenic formae of $F$. oxysporum can be recovered for agricultural production by reducing the amount of initial inoculum and/or its potential for disease to levels below the threshold for severe disease [57]. This aim can be achieved by means of chemical, physical or biological disease control methods.

Fusarium wilt diseases of several crops have been successfully controlled by soil solarization [60]. The heat generated by solarization may not kill a pathogen outright, but the organism may be weakened, resulting in a reduction of its aggressiveness for its host and greater susceptibility to attack by other components of the soil microflora [61]. In addition, soil-borne plant pathogen control could be realized by flooding that destroys many soil-borne pathogens $[57,61]$. Removal of debris from Fusarium-wilt affected chickpea crops and burning or flaming them to achieve thermal killing of Foc chlamydospores would reduce disease risk in the subsequent crop. Burning affected crop residues has been shown to greatly reduce the amount of soil-borne inoculum of several plant pathogenic fungi [23].

The use of bio-agents for control exhibit great potential. Indeed, a biological control agent colonizes the rhizosphere and leaves no toxic residues as opposed to chemicals [62]. The species of Trichoderma have been evaluated against the wilt pathogen and offer great promise in managing chickpea wilt under glasshouse and field conditions [63]. Furthermore, the use of Pseudomonas fluorescens inhibits the growth of F. oxysporum f. sp. ciceris in vitro and permits significant growth increases in shoot length, dry weight, and grain yield [64]. Treatment with Pseudomonas fluorrescens formulation increased chickpea yield in field and can be effectively used as seed treatments to control chickpea wilt [65]. In addition, Fravel et al. [66] attributed disease reduction to increased plant defense reactions in response to root colonization by the nonpathogenic strain of Fusarium spp. A study conducted with different isolates of Bacillus spp. and Pseudomonas chlororaphis showed a strong antagonism against three races of F. oxysporum f. sp. ciceris [67].

\subsection{Choice of Cropping Practices}

Environmental factors such as temperature, nutrients and soil $\mathrm{pH}$ can significantly influence the development of Fusarium wilt diseases, and proper choice of cultural practices that take advantage of such an influence can contribute to good management of Fusarium. A study conducted by Haware et al. [27] indicate that Fusarium chickpea wilt has the ability to survive in the soil for more than 6 years, and 3 years of crop rotation is not effective in reducing wilt incidence. According to a study conducted in southern Spain by Navas-Cortes [68], it was demonstrated that epidemic development was related mainly to sowing date. Thus, advancing the sowing date of chickpea crops from early spring to early winter can decelerate the development of Fusarium wilt epidemics and increase chickpea seed yield [41]. In view of these findings, host resistance seems to be the most efficient control method for chickpea wilt.

\subsection{Use of Resistant Cultivars}

Currently, the use of resistant cultivars appears to be the most practical and economically efficient control measure for management of chickpea Fusarium wilt. Resistant chickpea cultivars represent a key component in integrated disease management (IDM) programs that involve the use of additive or synergistic combinations of biotic, cultural, and chemical control measures [23,41,57,69]. Resistance to 
Foc races had been identified mainly in Desi germplasm and to a lesser extent in Kabuli chickpeas, as well as in wild Cicer spp. [23]. The deployment of resistant cultivars has not been extensive because of undesirable agronomic characteristics in some developed materials. Furthermore, the high pathogenic variability in Foc populations may limit the effectiveness and extensive use of available resistance [48].

\section{Resistance to Fusarium Wilt}

Chickpea resistance to Fusarium wilt has been reported to be monogenic or oligogenic depending upon the race or resistance source $[45,50,51]$. Early studies on genetic resistance to Foc revealed that resistance to race $1 \mathrm{~A}$ is governed by at least three independent genes namely $\mathrm{h} 1, \mathrm{~h} 2$, and $\mathrm{H} 3[15,50]$. Late wilting resistance is conferred by any one of these three genes, but a combination of any two of the late wilting genes confers complete resistance (h1h2 or h1H3 or h2H3) [12,23]. A similar genetic system based on two [70] or three [71] independent genes was found to confer resistance to race 2 [70,71]. Sharma et al. [51] demonstrate that resistance to race 2 is governed by a single recessive gene, whereas resistance to race 3 has been found to be monogenic [51,72]. Others studies showed that resistance to race 4 is recessive and digenic [73], while race 5 resistance is controlled by a single gene [74]. For Foc, race 0 resistance is controlled by two genes which segregate independently: $f o c 0_{1}$ present in accession JG-62, and $\mathrm{foc}_{2}$ present in lines CA-1938, CA-2139 and WR-315 [75-77]. Nevertheless, the genetic basis of resistance to races $1 \mathrm{~B} / \mathrm{C}$ and 6 is still unknown. Genetic resistance to Foc races was reviewed by Sharma and Muehlbauer [45], and some genes resistant to races $0,1,2,3,4$ and $5\left(f_{o c} 0_{2}\right.$, foc- 1 , foc-2, foc-3, foc- 4 and foc-5) are located on LG2 of the chickpea map [45,72,75,76,78,79]. However, one of the two resistance genes for race $0\left(f_{o c} 0_{1}\right)$ was found in LG5 [80] (Table 1).

Table 1. Associated markers for genes resistant to various Foc races in different linkage groups of the chickpea genetic map.

\begin{tabular}{|c|c|c|c|}
\hline LG & Genes & Associated Markers & References \\
\hline \multirow[t]{10}{*}{ LG2 } & $\mathrm{FocO}_{2} / \mathrm{focO}_{2}$ & TA59, TS47 & [75] \\
\hline & foc-1 & CS27 & [79] \\
\hline & & H3A12, TA110 & [72] \\
\hline & foc-2 & TA96, H3A12 & [72] \\
\hline & foc-3 & TA96, TA27, CS27A & [81] \\
\hline & & H1B06y, TA194 & [72] \\
\hline & foc- 4 & TA96, CS27 & [82] \\
\hline & & R-2609-1 & [83] \\
\hline & foc -5 & TA59, TA96 & [78] \\
\hline & & TA27 & [82] \\
\hline LG5 & $\mathrm{FocO}_{1} / \mathrm{focO}_{1}$ & OPJ20 600, TR59 & [80] \\
\hline
\end{tabular}

\section{Breeding Method for Fusarium Wilt Resistance}

Breeding efforts have contributed to significantly reduce the fusarium wilt effect on the chickpea crop.

Three main steps or components are generally involved in any chickpea breeding program: 1 / genetic variation, which is the base of the breeding program, 2/ selection within that variation for desirable plant types and disease resistance and $3 /$ evaluation of the selected lines for commercial production $[84,85]$. Since chickpea is self-pollinated, the development of pure-line cultivars requires fixing genes in breeding lines. Mass or pure-line selection from landraces was the simplest method initially employed. Later, crossing programs and various modifications of pedigree and bulk methods were used in handling segregating generations [6,14].

Single crosses have been adopted in most chickpea breeding programs, especially in intraspecific hybridization between Desi and Kabuli-types having different genetic backgrounds [86]. Desi parents have been used to transfer important genes to Fusarium wilt resistance into Kabuli-type breeding programs, conversely, Kabuli parents have been used as a source to improve large seed size and 
seed quality in Desi breeding programs [87]. Efforts have been made to use interspecific crosses for enhancing genetic variability and introgressing useful genes from wild cicer spp. into the cultivated species. Resistance to Foc races has been identified mainly in Desi germplasm as well as in wild cicer spp. Indeed, combined resistance against race 0 and 5 was identified in accessions of c. bijigum, c. cuneatum, c. judaicum, whereas accessions of $c$. canariense and c. chorassanicum were resistant to race 0 but susceptible to 5 . Moreover, accessions tested of $c$. pinnatifidum were susceptible to race 5 , but some were resistant to race 0 [88].

There is a need to enhance precision and efficiency of selections in the segregating generations for higher and rapid genetic gains [6]. Effective wilt sick-plot for the field and hot spot location screening, greenhouse and laboratory procedures for resistance screening have been developed for successful breeding programs [87]. Nene et al. [89] developed the field technique of screening for a "wilt-sick plot". The technique is outlined as follows: (i) Select a plot of adequate size cropped in the previous year with chickpea and isolated from other chickpea fields to avoid spread of the fungus inoculum from this plot to others; (ii) Collect wilted plants from other fields, chop into small pieces, and incorporate uniformly in the surface soil of the plot; (iii) Plant a highly susceptible cultivar in this plot. This will help increase the level of the inoculum to make the soil "sick". Such plots are available at many research stations around the world and are widely used for screening for fusarium wilt resistance. The methodology consists of planting a highly susceptible check every two test entries with two replications. The percentage of wilt incidence of each entry is calculated, and the level of resistance and susceptibility of each test entry is determined by using the appropriate rating scale [90]. Screening of over 13,500 Desi germplasm accessions for resistance to fusarium wilt using wilt-sick plots at ICRISAT (International Crops Research Institute for the Semi-Arid Tropics) allowed the identification of 165 sources of resistance [42]. Moreover, among 5174 Kabuli germplasm accessions screened for Fusarium wilt resistance at ICARDA (International Center for Agricultural Research in the Dry Areas), 110 lines were identified as resistant [91]. Some Kabuli accessions with high resistance to fusarium wilt have been identified: line ILC 9784 (races 0, 1A, and 5); lines ILC 9785, ILC 9786, FLIP 86-93C, FLIP 87-33C and FLIP 87-38C (races 0 and 1A) [92,93], and line CA-2954 (races 0 and 5) [94]. Moreover, several cultivars with stable resistance to fusarium wilt have been identified in many countries as USA, India, Israel, Mexico and Tunisia, including cvs. ICCV-2 through ICCV-6 (race 1A) [95] Amdoum 1, Béja1, Nour (race 0) [96,97], and Gavilan, Surutato-77, Sonora-80, Tubutama, UC-15 and UC-27 [98-100]. For these six later cultivars, resistance introgressed from Desi line L- 1186 is effective against races 0 , $1 \mathrm{~A}, 1 \mathrm{~B} / \mathrm{C}, 5$, and 6 and it has been operative in California, Mexico, and Spain [101,102].

\section{Integration of Genomic Technologies in Chickpea Breeding Program}

\subsection{Genetic Maps}

Acceleration and facilitation of the selection of segregating plant material constitutes the main objective of breeders. In chickpea, efforts have been underway to develop saturated genetic maps for tagging traits with molecular markers, thus enabling their use in Marker Assisted Selection (MAS) and positional cloning of genes of interest [5,14].

The first genetic maps developed in chickpea were obtained by analyzing isozymes in $F_{2}$ populations from interspecific crosses [103]. Since then, many maps have been developed by different research groups. Genes that control different characters such as flower color, double pod, growth habit and Fusarium wilt resistance $[45,80,104-107]$ as well as QTLs (Quantitative Traits Loci) associated with flowering time, agronomics traits and ascochyta blight resistance were located on these maps $[1,78,108]$.

The greatest number of maps including a large number of markers were achieved using populations derived from crosses with $C$. reticulatum [78,82,109-112]. Nevertheless, mapping populations derived from intraspecific crosses were obtained due to the development of microsatellite markers that detect a greater number of polymorphisms $[1,80,108,113,114]$. Millan et al. [5] stated that the use of Sequence Tagged Microsatellite Site (STMS) markers in different mapping populations offers the possibility of 
building a consensus chickpea map using information from different maps and following a reference map previously proposed by Winter et al. [82]. Recently, thanks to the development of next-generation sequencing technologies, the first chickpea transcriptome was obtained [115]. Comprehensive genetic maps with large-scale molecular markers were obtained using the transcriptome information [116-118].

Moreover, the availability of the draft genome in Desi and Kabuli chickpea has opened the possibility of anchoring genetic maps and positioning QTL on the physical one [2,119-121]. Nowadays, genomic information will certainly boost the development of markers with complete association with QTLs [122].

Development of diagnostic molecular markers from coding sequences with a knowledge function could be used in the screening of germplasm collections or breeding materials, improving the efficiency and effectiveness of conventional breeding methods [123]. For example, a plant specific transcription factor Ein3 coding for an ethylene insensitive 3-like protein has been transformed into a molecular marker. This marker explained $44 \%$ of the total phenotypic variation for resistance to blight in chickpea [123], which could be useful for MAS approaches [124].

\subsection{Marker-Assisted Selection (MAS)}

Integration of genomics tools in chickpea breeding programs such as marker-assisted selection (MAS) is very promising for crop improvement [6]. The effectiveness of MAS depends on the strength of the linkage between the marker and the gene locus controlling the trait of interest, the localization in a saturated genomic area, the high level of polymorphism, and ease of interpretation $[4,14]$. For instance, the fundamental advantages of MAS over conventional selection are the possibility of selection for traits that are difficult or inconvenient to score directly, avoiding complex and time consuming evaluations, mainly in the case of breeding for disease resistance. MAS also facilitates the pyramiding of different resistance genes in the same genotype, resulting in faster line development and variety release [14,125].

MAS has not been widely adopted in chickpea breeding programs for resistance despite the availability of a saturated genetic map and markers tightly linked to a gene or QTLs. Recently, marker-assisted backcrossing was successfully employed to introgress Ascochyta blight resistance with double-podding traits in chickpea cultivars. Microsatellite markers were also employed in each backcross generation to assist selection for resistance to Fusarium wilt race 1 and blight [126,127].

Sequence characterized amplified regions (SCARs) SCY17 $7_{590}$ and SCAE19 ${ }_{336}$ tightly linked to QTL $_{\mathrm{AR} 2}$ for Ascochyta blight resistance, previously developed by [128], and used to tag resistance lines in a collection of chickpea germplasm [129]. Using the SCAR marker SCY17 590 in combination

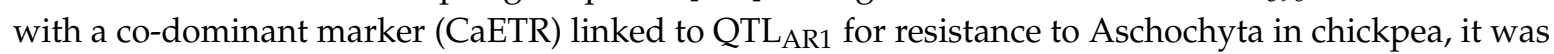
possible to detect resistance alleles in $90 \%$ of resistant accessions in a collection of landraces [130]. Recently, efficient contribution of both markers in MAS of blight-resistant genotypes in different breeding programs in Tunisia and Spain have been reported [131,132].

STMS markers tightly linked to foc5 (TA59) and to foc0 $0_{1}$ (TR59, TS35) in LG2 and LG5 were used to assist selection of resistant and susceptible genotypes and to develop near isogenic lines (NILs) $[133,134]$. Indeed, NILs represent a valuable tool for fine mapping, refining the target region and selecting candidate genes for resistance to Foc 0 . Recently, three recombinant inbred populations were used to validate and saturate the target area involved in the resistance to Foc0 in chickpeas by Jendoubi et al. [134]. Results obtained by Jendoubi et al. [134] were useful to refine the position of the target area involved in resistance mechanisms. Previous studies conducted by Ali et al. $[119,121]$ pointed out the identification of target regions controlling growth habit and double podding in chickpea based on the physical position of the marker.

\section{Conclusions}

Several pathogenic fusarium spp. such as F. redolens [19] may cause similar symptoms in chickpea as Foc. These features emphasize the importance of assuring accurate identification and discrimination between pathogenic Fusarium spp. that show similar symptoms in a determined geographical area for 
which suitable molecular protocols are available. This approach would facilitate a better understanding of the etiology and epidemiology of the disease caused by the different Fusarium spp. and accelerate the development of new resistant chickpea cultivars. The development of efficient molecular markers in plant breeding will continue to be a very dynamic process in the coming years. Indeed, identifying molecular markers closely linked to a gene/QTL controlling a trait is a prerequisite for applying marker-assisted selection (MAS) in a conventional breeding program. Therefore, incorporating MAS for wilt resistance into breeding programs is a valuable tool that would greatly improve the efficiency of selection.

Acknowledgments: This review was written in the framework of Ph.D. Program of W. Jendoubi. W. Jendoubi was supported by a fellowship from the MESRT (Ministère de l'Enseignement Supérieur et de la Recherche Scientifique-Tunisie) and the Tunisian Project on Chickpeas (Efficacité de la sélection assistee par marqueurs dans la détection de génotypes de pois chiche résistants aux principales maladies fongiques en Tunisie) funded by IRESA (Institution de la Recherche et de l'Enseignement Supérieur Agricole-Ministère de l'Agriculture).

Author Contributions: All authors contributed significantly to the work presented in this paper. Warda Jendoubi and Mariem Bouhadida prepared the first draft of the manuscript, Amal Boukteb, Mohamed Béji and Mohamed Kharrat edited and integrated suggestions and recommendations to produce the final form of the manuscript.

Conflicts of Interest: The authors declare no conflict of interest.

\section{References}

1. Cobos, M.J.; Rubio, J.; Fernández-Romero, M.D.; Garza, R.; Moreno, M.T.; Millán, T.; Gil, J. Genetic analysis of seed size, yield and days to flowering in a chickpea recombinant inbred line population derived from a Kabuli $\times$ Desi cross. Ann. Appl. Biol. 2007, 151, 33-42. [CrossRef]

2. Varshney, R.K.; Song, C.; Saxena, R.K.; Azam, S.; Yu, S.; Sharpe, A.G.; Cannon, S.; Baek, J.; Rosen, B.D.; Tar'an, B.; et al. Draft genome sequence of chickpea (Cicer arietinum) provides a resource for trait improvement. Nat. Biotechnol. 2013, 31, 240-246. [CrossRef] [PubMed]

3. Lichtenzveig, J.; Scheuring, C.; Dodge, J.; Abbo, S.; Zhang, H.-B. Construction of BAC and BIBAC libraries and their applications for generation of SSR markers for genome analysis of chickpea, Cicer arietinum L. Theor. Appl. Genet. 2005, 110, 492-510. [CrossRef] [PubMed]

4. Singh, R.; Sharma, P.; Varshney, R.K.; Sharma, S.K.; Singh, N.K. Chickpea Improvement: Role of Wild Species and Genetic Markers. Biotechnol. Genet. Eng. Rev. 2008, 25, 267-314. [CrossRef] [PubMed]

5. Millan, T.; Winter, P.; Jüngling, R.; Gil, J.; Rubio, J.; Cho, S.; Cobos, M.J.; Iruela, M.; Rajesh, P.N.; Tekeoglu, M.; et al. A consensus genetic map of chickpea (Cicer arietinum L.) based on 10 mapping populations. Euphytica 2010, 175, 175-189. [CrossRef]

6. Gaur, P.M.; Jukanti, A.K.; Varshney, R.K. Impact of Genomic Technologies on Chickpea Breeding Strategies. Agronomy 2012, 2, 199-221. [CrossRef]

7. Roy, F.; Boye, J.I.; Simpson, B.K. Bioactive proteins and peptides in pulse crops: Pea, chickpea and lentil. Food Res. Int. 2010, 43, 432-442. [CrossRef]

8. Jukanti, A.K.; Gaur, P.M.; Gowda, C.L.L.; Chibbar, R.N. Nutritional quality and health benefits of chickpea (Cicer arietinum L.): A review. Br. J. Nutr. 2012, 108, S11-S26. [CrossRef] [PubMed]

9. Maheri, N.; Chamani, M.; Sadeghi, A.A.; Aghazadeh, A.A.; Golshani, A.A. Nutritional evaluation of kabuli and desi type chickpeas (Cicer arietinum L.) for ruminants using in vitro gas production technique. Afr. J. Biotechnol. 2008, 7, 2946-2951.

10. Agarwal, G.; Jhanwar, S.; Priya, P.; Singh, V.K.; Saxena, M.S.; Parida, S.K.; Garg, R.; Tyagi, A.K.; Jain, M. Comparative Analysis of Kabuli Chickpea Transcriptome with Desi and Wild Chickpea Provides a Rich Resource for Development of Functional Markers. PLoS ONE 2012, 7, e52443. [CrossRef] [PubMed]

11. Singh, K.B.; Malhotra, R.S.; Halila, M.H.; Knights, E.J.; Verma, M.M. Current status and future strategy in breeding chickpea for resistance to biotic and abiotic stresses. Euphytica 1993, 73, 137-149. [CrossRef]

12. Castro, P.; Rubio, J.; Millán, T.; Gil, J.; Cobos, M.J. Fusarium wilt in chickpea: General aspect and molecular breeding. In Fusarium: Epidemiology, Environmental Sources and Prevention; Rios, T.F., Ortega, E.R., Eds.; Nova Science Publishers: New York, NY, USA, 2012; pp. 101-122.

13. FAOSTAT. Food and Agriculture Data. Available online: http:/ / faostat.fao.org (accessed on 15 October 2016). 
14. Millan, T.; Madrid, E.; Cubero, J.I.; Amri, M.; Castro, P.; Rubio, J. Chickpea. In Grain Legumes; De Ron Antonio, M., Ed.; Springer: New York, NY, USA, 2015.

15. Singh, S.; Singh, I.; Kapoor, K.; Gaur, P.M.; Chaturvedi, S.K.; Singh, N.P.; Sandhu, J.S. Chickpea. In Broadening the Genetic Base of Grain Legumes; National Bureau of Plant Genetic Resources: New Delhi, India, 2014.

16. Cunnington, J.; Lindbeck, K.; Jones, R.H. National Diagnostic Protocol for the Detection of Fusarium Wilt of Chickpea (Fusarium Oxysporum f. sp. ciceris). Plant Health Australia: Camberra, Australia, 2007.

17. Haware, M.P.; Nene, Y.L. Races of Fusarium oxysporum f.sp. ciceri. Plant Dis. 1982, 66, 809-810. [CrossRef]

18. Halila, M.H.; Strange, R.N. Screening of Kabuli chickpea germplasm for resistance to Fusarium wilt. Euphytica 1997, 96, 273-279. [CrossRef]

19. Jimenez-Fernandez, D.; Navas-Cortes, J.A.; Montes-Borrego, M.; Jimenez-Diaz, R.M.; Landa, B.B. Molecular and Pathogenic Characterization of Fusarium redolens, a New Causal Agent of Fusarium Yellows in Chickpea. Plant Dis. 2011, 95, 860-870. [CrossRef]

20. Landa, B.B.; Navas-Cortés, J.A.; Jiménez-Gasco, M.M.; Katan, J.; Retig, B.; Jiménez-Díaz, R.M. Temperature response of chickpea cultivars to races of Fusarium oxysporum f. sp. ciceris, causal agent of Fusarium wilt. Phytopathology 2006, 90, 365-374.

21. Haware, M.P. Fusarium wilt and other important diseases chickpea in the Mediterranean area. In Present Status and Future Prospects of Chickpea Crop Production and Improvement in the Mediterranean Countries; Saxena, M.C., Cubero, J.I., Wery, J., Eds.; CIHEAM: Zaragoza, Spain, 1990; pp. 61-64.

22. Jimenez Diaz, R.M.; Jimenez Gasco, M.M.; Landa, B.B.; Castillo, P.; Navas-Cortes, J.A. Fusarium Wilt of chikpea. In Compendium of Chikpea and Lentil Diseases and Pests; Chen, W., Sharma, H.C., Muehlbauer, F.J., Eds.; The American Phytopathological Society: St. Paul, MN, USA, 2011.

23. Jiménez-Díaz, R.M.; Castillo, P.; del Mar Jiménez-Gasco, M.; Landa, B.B.; Navas-Cortés, J.A. Fusarium wilt of chickpeas: Biology, ecology and management. Crop Prot. 2015, 73, 16-27. [CrossRef]

24. Al-taae, A.K.; Hadwan, H.A.; Al-jobory, S.A.E. Physiological Races of Fusarium oxysporum f. sp. Ciceris in Iraq. J. Life Sci. 2013, 7, 1070-1075.

25. Haware, M.P.; Nene, Y.L. Influence of wilt and different growth stages on yield loss in chickpea. Trop. Grain Legum. Bull. 1980, 19, 38-40.

26. Navas-Cortés, J.A.; Hau, B.; Jiménez-Díaz, R.M. Yield loss in chickpeas in relation to development of Fusarium wilt epidemics. Phytopathology 2000, 90, 1269-1278. [CrossRef] [PubMed]

27. Haware, M.P.; Nene, Y.L.; Natarajan, M. The survival of Fusarium oxysporum f. sp. ciceri in the soil in the absence of chickpea. Phytopathol. Mediterr. 1996, 35, 9-12.

28. Haware, M.P.; Nene, Y.L.; Rajeshwari, R. Eradication of Fusarium oxysporum f. sp. ciceri transmitted in chickpea seed. Phytopathology 1978, 68, 1364-1367. [CrossRef]

29. Shakir, A.S.; Mirza, J.H. Location of seed-borne fungi in chickpea seed. Pakistan J. Phytopathol. 1994, 6, 87-90.

30. Chand, H.; Khirbat, S.K. Chickpea Wilt and Its Management-A Review. Agric. Rev. 2009, 30, 1-12.

31. Schippers, B.; van Eck, W.H. Formation and survival of chlamydospores in Fusarium. In Fusarium: Diseases, Biology and Taxonomy; The Pennysylvania State University Press: London, UK, 1981.

32. Trapero-Casas, A.; Jimenez-Diaz, R.M. Fungal wilt and root rot diseases of chickpea in southern Spain. Phytopathology 1985, 75, 1146-1151. [CrossRef]

33. Nelson, P.E. Life Cycle and Epidemiology of Fusarium oxysporum. In Fungal Wilt Diseases of Plants; Mace, M., Bell, A.A., Beckman, C., Eds.; Academic Press: London, UK, 2012; pp. 51-78.

34. Beckman, C.H.; Roberts, E.M. On the nature and genetic basis for resistance and tolerance of fungal wilt diseases. In Advances in Botanical Research; Academic Press: London, UK, 1995.

35. Stover, R.H. Banana root diseases caused by Fusarium oxysporum f. sp. Cubense, Pseudomonas solanacearum, and Radopholus similis: A comparative study of life cycles in relation to control. In Root diseases and soil-borne pathogens; Toussoun, T.A., Bega, R.V., Nelson, P., Eds.; University California Press: Oakland, CA, USA, 1970.

36. Lucas, J. Plant diseases. In Plant pathology and plant pathogens; Blackwell Publishing: Malden, MA, USA, 1998.

37. Mendgen, K.; Hahn, M.; Deising, H. Morphogenesis and mechanisms of penetration by plant pathogenic fungi. Annu. Rev. Phytopathol. 1996, 34, 367-386. [CrossRef] [PubMed]

38. Bishopt, G.D.; Cooper, R.M. An ultrastructural study of root invasion in three vascular wilt diseases. Physiol. Plant Pathol. 1983, 22, 15-27. [CrossRef]

39. Beckman, C.H. The nature of wilt diseases of plants; American Phytopathological Society: St Paul., MN, USA, 1987. 
40. Halila, M.H.; Strange, R.N. Identification of the causal agent of wilt of chickpea in Tunisia as Fusarium oxysporum f. sp. ciceri race 0. Phytopathol. Mediterr. 1996, 35, 67-74.

41. Landa, B.B.; Navas-Cortés, J.A.; Jiménez-Díaz, R.M. Integrated management of fusarium wilt of chickpea with sowing date, host resistance, and biological control. Phytopathology 2004, 94, 946-960. [CrossRef] [PubMed]

42. Haware, M.P.; Nene, Y.L.; Pundir, R.P.S.; Rao, J.N. Screening of world chickpea germplasm for resistance to fusarium wilt. F. Crop. Res. 1992, 30, 147-154. [CrossRef]

43. Jiménez-Gasco, M.M.; Navas-Cortés, J.A.; Jiménez-Díaz, R.M. The Fusarium oxysporum f. sp. ciceris /Cicer arietinum pathosystem: A case study of the evolution of plant-pathogenic fungi into races and pathotypes. Int. Microbiol. 2004, 7, 95-104.

44. Jiménez-Fernández, D.; Landa, B.B.; Kang, S.; Jiménez-Díaz, R.M.; Navas-Cortés, J.A. Quantitative and Microscopic Assessment of Compatible and Incompatible Interactions between Chickpea Cultivars and Fusarium oxysporum f. sp. ciceris Races. PLoS ONE 2013, 8, e61360.

45. Sharma, K.D.; Muehlbauer, F.J. Fusarium wilt of chickpea: Physiological specialization, genetics of resistance and resistance gene tagging. Euphytica 2007, 157, 1-14. [CrossRef]

46. Jiménez-Gasco, M.D.M.; Jiménez-Díaz, R.M. Development of a Specific Polymerase Chain Reaction-Based Assay for the Identification of Fusarium oxysporum f. sp. ciceris and Its Pathogenic Races 0, 1A, 5, and 6. Phytopathology 2003, 93, 200-209.

47. Jiménez-Gasco, M.; Pérez-Artés, E.; Jiménez-Diaz, R.M. Identification of Pathogenic Races 0, 1B/C, 5, and 6 of Fusarium oxysporum f. sp. ciceris with Random Amplified Polymorphic DNA (RAPD). Eur. J. Plant Pathol. 2001, 107, 237-248.

48. Bayraktar, H.; Dolar, F.S. Pathogenic variability of Fusarium oxysporum f. sp. ciceris isolates from chickpea in Turkey. Pakistan J. Bot. 2012, 44, 821-823.

49. Shehabu, M.; Ahmed, S.; Sakhuja, P.K. Pathogenic variability in Ethiopian isolates of Fusarium oxysporum $\mathrm{f}$. sp. ciceris and reaction of chickpea improved varieties to the isolates. Int. J. Pest Manag. 2008, 54, 143-149. [CrossRef]

50. Upadhyaya, H.D.; Haware, M.P.; Kumar, J.; Smithson, J.B. Resistance to wilt in chickpea. I. Inheritance of late-wilting in response to race 1. Euphytica 1983, 32, 447-452. [CrossRef]

51. Sharma, K.D.; Chen, W.; Muehlbauer, F.J. Genetics of chickpea resistance to five races of fusarium wilt and a concise set of race differentials for Fusarium oxysporum f. sp. ciceris. Plant Dis. 2005, 89, 385-390. [CrossRef]

52. Clarkson, J.D.S. Pathogenicity of Fusarium spp. Associated with Foot-rots of Peas and Beans. Plant Pathol. 1978, 27, 110-117. [CrossRef]

53. Bienapfl, J.C.; Malvick, D.K.; Percich, J.A. First Report of Fusarium redolens Causing Root Rot of Soybean in Minnesota. Plant Dis. 2010, 94, 1069. [CrossRef]

54. Riccioni, L.; Haegi, A.; Valvassori, M. First Report of Vascular Wilt Caused by Fusarium redolens on Lentil in Italy. Plant Dis. 2008, 92, 1132. [CrossRef]

55. Baayen, R.P.; van Den Boogert, P.H.J.F.; Bonants, P.J.M.; Poll, J.T.K.; Blok, W.J.; Waalwijk, C. Fusarium redolens f.sp. asparagi, causal agent of asparagus root rot, crown rot and spear rot. Eur. J. Plant Pathol. 2000, 106, 907-912. [CrossRef]

56. Bouhadida, M.; Jendoubi, W.; Gargouri, S.; Beji, M.; Kharrat, M.; Chen, W. First report of Fusarium redolens causing Fusarium yellowing and wilt of chickpea in Tunisia. Plant Dis. 2017. [CrossRef]

57. Jiménez-díaz, R.M.; Jiménez-gasco, M.M. Integrated Management of Fusarium Wilt Diseases. In Control of Fusarium Diseases; Transworld Research Network: Kerala, India, 2011; pp. 177-215.

58. Nelson, P.E.; Tousson, T.A.; Cook, R.J. Fusarium: Diseases, Biology and Taxonomy; Pennsylvania State University Press: University Park, PA, USA, 1981.

59. Jiménez-Fernández, D.; Montes-Borrego, M.; Jiménez-Díaz, R.M.; Navas-Cortés, J.A.; Landa, B.B. In Planta and Soil Quantification of Fusarium oxysporum f. sp. ciceris and Evaluation of Fusarium Wilt Resistance in Chickpea with a Newly Developed Quantitative Polymerase Chain Reaction Assay. Phytopathology 2011, 101, 250-262.

60. Stapleton, J.J.; de Vay, J.E. Soil solarization: A non-chemical approach for management of plant pathogens and pests. Crop Prot. 1986, 5, 190-198. [CrossRef]

61. Strange, R.N. Introduction to Plant Pathology; John Wiley \& Sons Ltd.: London, UK, 2003. 
62. Dubey, S.C.; Suresh, M.; Singh, B. Evaluation of Trichoderma species against Fusarium oxysporum f. sp. ciceris for integrated management of chickpea wilt. Biol. Control 2007, 40, 118-127.

63. Kaur, N.P.; Mukhopadhyay, A.N. Integrated Control of Chickpea Wilt Complex by Trichoderma and Chemical Methods in India. Trop. Pest Manag. 1992, 38, 37-41. [CrossRef]

64. Nautiyal, C.S. Selection of Chickpea-Rhizosphere-Competent Pseudomonas fluorescens NBRI1303 Antagonistic to Fusarium oxysporum f. sp. ciceri, Rhizoctonia bataticola and Pythium sp. Curr. Microbiol. 1997, 35, 52-58. [CrossRef]

65. Vidhyasekaran, P.; Muthamilan, M. Development of Formulations of Pseudomonas fluorescens for Control of Chickpea Wilt. Plant Dis. 1995, 79, 782-786. [CrossRef]

66. Fravel, D.; Olivain, C.; Alabouvette, C. Fusarium oxysporum and its biocontrol. New Phytol. 2003, 157, 493-502. [CrossRef]

67. Landa, B.B.; Hervás, A.; Bettiol, W.; Jiménez-Díaz, R.M. Antagonistic activity of Bacteria from the chickpea rhizosphere against Fusarium Oxysporum f. sp. ciceris. Phytoparasitica 1997, 25, 305-318. [CrossRef]

68. Navas-Cortés, J.A.; Hau, B.; Jiménez-Díaz, R.M. Effect of Sowing Date, Host Cultivar, and Race of Fusarium oxysporum f. sp. ciceris on Development of Fusarium Wilt of Chickpea. Phytopathology 1998, 88, 1338-1346.

69. Conway, K.E. An overview of the influence of sustainable agricultural systems on plant diseases. Crop Prot. 1996, 15, 223-228. [CrossRef]

70. Gumber, R.K.; Kumar, J.; Hanaware, M.P. Inheritance of resistance to fusarium wilt in chickpea. Plant Breed. 1995, 114, 277-279. [CrossRef]

71. Kumar, S. Inheritance of resistance to Fusarium wilt (race 2) in chickpea. Plant Breed. 1998, 117, 139-142. [CrossRef]

72. Gowda, S.J.M.; Radhika, P.; Kadoo, N.Y.; Mhase, L.B.; Gupta, V.S. Molecular mapping of wilt resistance genes in chickpea. Mol. Breed. 2009, 24, 177-183. [CrossRef]

73. Tullu, A.; Kaiser, W.J.; Kraft, J.M.; Muehlbauer, F.J. A second gene for resistance to race 4 of Fusarium wilt in chickpea and linkage with a RAPD marker. Euphytica 1999, 109, 43-50. [CrossRef]

74. Tekeoglu, M.; Tullu, A.; Kaiser, W.J.; Muehlbauer, F.J. Inheritance and linkage of two genes that confer resistance to fusarium wilt in chickpea. Crop Sci. 2000, 40, 1247-1251. [CrossRef]

75. Halila, I.; Cobos, M.J.; Rubio, J.; Millán, T.; Kharrat, M.; Marrakchi, M.; Gil, J. Tagging and mapping a second resistance gene for Fusarium wilt race 0 in chickpea. Eur. J. Plant Pathol. 2009, 124, 87-92. [CrossRef]

76. Halila, I.; Rubio, J.; Millán, T.; Gil, J.; Kharrat, M.; Marrakchi, M. Resistance in chickpea (Cicer arietinum) to Fusarium wilt race "0". Plant Breed. 2010, 129, 563-566. [CrossRef]

77. Rubio, J.; Hajj-Moussa, E.; Kharrat, M.; Moreno, M.T.; Millan, T.; Gil, J. Two genes and linked RAPD markers involved in resistance to Fusarium oxysporum f. sp. ciceris race 0 in chickpea. Plant Breed. 2003, 122, 188-191. [CrossRef]

78. Cobos, M.J.; Winter, P.; Kharrat, M.; Cubero, J.I.; Gil, J.; Millan, T.; Rubio, J. Genetic analysis of agronomic traits in a wide cross of chickpea. F. Crop. Res. 2009, 111, 130-136. [CrossRef]

79. Mayer, M.S.; Tullu, A.; Simon, C.J.; Kumar, J.; Kaiser, W.J.; Kraft, J.M.; Muehlbauer, F.J. Development of a DNA Marker for Fusarium Wilt Resistance in Chickpea. Crop Sci. 1997, 37, 1625-1629. [CrossRef]

80. Cobos, M.J.; Fernández, M.J.; Rubio, J.; Kharrat, M.; Moreno, M.T.; Gil, J.; Millán, T. A linkage map of chickpea (Cicer arietinum L.) based on populations from Kabuli $\times$ Desi crosses: Location of genes for resistance to fusarium wilt race 0. Theor. Appl. Genet. 2005, 110, 1347-1353. [CrossRef] [PubMed]

81. Sharma, K.D.; Winter, P.; Kahl, G.; Muehlbauer, F.J. Molecular mapping of Fusarium oxysporum f. sp. ciceris race 3 resistance gene in chickpea. Theor. Appl. Genet. 2004, 108, 1243-1248. [PubMed]

82. Winter, P.; Benko-Iseppon, A.-M.; Hüttel, B.; Ratnaparkhe, M.; Tullu, A.; Sonnante, G.; Pfaff, T.; Tekeoglu, M.; Santra, D.; Sant, V.J.; et al. A linkage map of the chickpea (Cicer arietinum L.) genome based on recombinant inbred lines from a C. arietinum $\times$ C. reticulatum cross: Localization of resistance genes for fusarium wilt races 4 and 5. Theor. Appl. Genet. 2000, 101, 1155-1163. [CrossRef]

83. Benko-Iseppon, A.-M.; Winter, P.; Huettel, B.; Staginnus, C.; Muehlbauer, F.J.; Kahl, G. Molecular markers closely linked to fusarium resistance genes in chickpea show significant alignments to pathogenesis-related genes located on Arabidopsis chromosomes 1 and 5. Theor. Appl. Genet. 2003, 107, 379-386. [CrossRef] [PubMed]

84. Salimath, P.M.; Toker, C.; Sandhu, J.S.; Kumar, J.; Suma, B.; Yadav, S.S.; Bahl, P.N. Conventional breeding methods. In Chickpea Breeding and Management; Yadav, S.S., Redden, R.J., Chen, W., Sharma, B., Eds.; Centre for Agriculture and Bioscience International (CABI): Wallingford, UK, 2007. 
85. Singh, K.B. Chickpea Breeding. In The Chickpea; Centre for Agriculture and Bioscience International (CABI): Wallingford, UK, 1987.

86. Berrada, A.F.; Shivakumar, B.G.; Yaburaju, N.T. Chickpea in cropping systems. In Chickpea Breeding and Management; Yadav, S.S.S., Redden, R., Chen, W., Sharma, B., Eds.; CABI Publishing: Wallingford, UK, 2007; pp. 193-212.

87. Gaur, P.M.; Gowda, C.L.L.; Knights, E.J.; Warkentin, T.; Acikoz, N.; Yadav, S.S.; Kumar, J. Breeding Achivements. In Chickpea Breeding; Centre for Agriculture and Bioscience International (CABI): Wallingford, UK, 2007.

88. Kaiser, W.J.; Alcala-Jimenez, A.R.; Hervas-Vargas, A.; Trapero-Casas, J.L.; Jiménez-Díaz, R.M. Screening of wild Cicer species for resistance to races 0 and 5 of Fusarium oxysporum f. sp. ciceris. Plant Dis. 1994, 78, 962-967. [CrossRef]

89. Nene, Y.L.; Haware, M.P.; Reddy, M.V. Chickpea diseases: Resistance-screening techniques; International Crops Research Institute for the Semi-Arid Tropics: Patancheru, India, 1981.

90. Iqbal, S.M.; Ghafoor, A.; Bakhsh, A.; Ahmad, I.; Sher, A. Identification of resistant sources for multiple disease resistance in chickpea. Pak. J. Phytopathol 2010, 22, 89-94.

91. Singh, K.B. Chickpea (Cicer arietinum L.). F. Crop. Res 1997, 53, 161-170. [CrossRef]

92. Jiménez-Díaz, R.M.; Singh, K.B.; Trapero-Casas, A.; Trapero-Casas, J.L. Resistance in kabuli chickpeas to Fusarium wilt. Plant Dis. 1991, 75, 914-918. [CrossRef]

93. Singh, K.B.; Jiménez-Díaz, R.M. Registration of Six Fusarium Wilt-Resistant Chickpea Germplasm Lines. Crop Sci. 1996, 36, 817. [CrossRef]

94. Rubio, J.; Martinez, C.; Gil, J.; Moreno, M.T. Registration of ascochyta blight and fusarium wilt resistant CA2954 kabuli chickpea germplasm. Crop Sci. 2004, 44, 1881-1883. [CrossRef]

95. Kumar, J.; Haware, M.P.; Smithson, J.B. Registration of four short duration Fusarium wilt-resistant Kabuli (Garbanzo) chickpea germplasm. Crop Sci 1985, 25, 576-577. [CrossRef]

96. Halila, M.H.; Harrabi, M.M. Breeding for dual resistance to Ascochyta and wilt diseases in chickpea. In Present Status and Future Prospects of Chickpea Crop Production and Improvement in the Mediterranean Countries; Saxena, M.C., Cubero, J.I., Wery, J., Eds.; The International Centre for Advanced Mediterranean Agronomic Studies (CIHEAM): Zaragoza, Spain, 1990; pp. 163-166.

97. Amri, M.; Bouhadida, M.; Halila, M.H.; Kharrat, M. Chickpea cropping and breeding program: An overview on the Tunisian situation. In Legume perspectives; Rubiales, D., Ed.; International Legume Society (ILS): Cordoba, Spain, 2014; pp. 58-61.

98. Buddenhagen, I.W.; Workneh, F.; Bosque-Perez, N.A. Chickpea improvement and chickpea diseases in California. Int. Chickpea Newsl. 1988, 19, 9-10.

99. Helms, D.; Pamella, L.; Buddenhagen, I.W.; Workneh, F.; Tucker, C.L.; Foster, K.W.; Gepts, P.L. Registration of "UC 15" chickpea. Crop Sci. 1992, 32, 500. [CrossRef]

100. Morales, G.J.A. Chickpea breeding program in Sonora, Mexico. Int. Chickpea Newsl. 1986, 15, 11-12.

101. Jimenez-Díaz, R.M.; Trapero-Casas, A.; Trapero-Casas, J.L. The use of host resistance to control Fusarium wilt of kabuli chickpeas. In Biological Control of Plant Diseases, Progress and Challenges for the Future; Tjamos, E.C., Cook, R.J., Papavizas, C., Eds.; Plenum Press: New York, NY, USA, 1992; pp. 359-362.

102. Jimenez-Díaz, R.M.; Crino, P.; Halila, M.H.; Mosconi, C.; Trapero-Casas, A. Screening for resistance to Fusarium wilt and Ascochyta blight in chickpea. In Breeding for Stress Tolerance in Cool-Season Food Legumes; Singh, K.B., Saxena, M.C., Eds.; John Wiley \& Sons: Chichester, UK, 1993; pp. 77-96.

103. Gaur, P.M.; Slinkard, A.E. Genetic control and linkage relations of additional isozyme markers in chick-pea. Theor. Appl. Genet. 1990, 80, 648-656. [CrossRef] [PubMed]

104. Kazan, K.; Muehlbauer, F.J.; Weeden, N.E.; Ladizinsky, G. Inheritance and linkage relationships of morphological and isozyme loci in chickpea (Cicer arietinum L.). Theor. Appl. Genet. 1993, 86, 417-426. [CrossRef] [PubMed]

105. Simon, C.J.; Muehlbauer, F.J. Construction of a chickpea linkage map and its comparison with maps of pea and lentil. J. Hered. 1997, 88, 115-119. [CrossRef]

106. Rajesh, P.N.; Tullu, A.; Gil, J.; Gupta, V.S.; Ranjekar, P.K.; Muehlbauer, F.J. Identification of an STMS marker for the double-podding gene in chickpea. Theor. Appl. Genet. 2002, 105, 604-607. [PubMed]

107. Cho, S.; Kumar, J.; Shultz, J.L.; Anupama, K.; Tefera, F.; Muehlbauer, F.J. Mapping genes for double podding and other morphological traits in chickpea. Euphytica 2002, 128, 285-292. [CrossRef] 
108. Lichtenzveig, J.; Bonfil, D.J.; Zhang, H.-B.; Shtienberg, D.; Abbo, S. Mapping quantitative trait loci in chickpea associated with time to flowering and resistance to Didymella rabiei the causal agent of Ascochyta blight. Theor. Appl. Genet. 2006, 113, 1357-1369. [CrossRef] [PubMed]

109. Winter, P.; Pfaff, T.; Udupa, S.M.; Hüttel, B.; Sharma, P.C.; Sahi, S.; Arreguin-Espinoza, R.; Weigand, F.; Muehlbauer, F.J.; Kahl, G. Characterization and mapping of sequence-tagged microsatellite sites in the chickpea (Cicer arietinum L.) genome. Mol. Gen. Genet. 1999, 262, 90-101. [CrossRef] [PubMed]

110. Tekeoglu, M.; Rajesh, P.; Muehlbauer, F. Integration of sequence tagged microsatellite sites to the chickpea genetic map. Theor. Appl. Genet. 2002, 105, 847-854. [PubMed]

111. Nayak, S.N.; Zhu, H.; Varghese, N.; Datta, S.; Choi, H.K.; Horres, R.; Jüngling, R.; Singh, J.; Kishor, P.B.K.; Sivaramakrishnan, $\mathrm{S}$; et al. Integration of novel SSR and gene-based SNP marker loci in the chickpea genetic map and establishment of new anchor points with Medicago truncatula genome. Theor. Appl. Genet. 2010, 120, 1415-1441. [CrossRef] [PubMed]

112. Cobos, M.J.; Rubio, J.; Strange, R.N.; Moreno, M.T.; Gil, J.; Millan, T. A new QTL for Ascochyta blight resistance in an RIL population derived from an interspecific cross in chickpea. Euphytica 2006, 149, $105-111$. [CrossRef]

113. Flandez-Galvez, H.; Ford, R.; Pang, E.C.K.; Taylor, P.W.J. An intraspecific linkage map of the chickpea (Cicer arietinum $\mathrm{L}$.) genome based on sequence tagged microsatellite site and resistance gene analog markers. Theor. Appl. Genet. 2003, 106, 1447-1456. [CrossRef] [PubMed]

114. Udupa, S.; Baum, M. Genetic dissection of pathotype-specific resistance to ascochyta blight disease in chickpea (Cicer arietinum L.) using microsatellite markers. Theor. Appl. Genet. 2003, 106, 1196-1202. [CrossRef] [PubMed]

115. Hiremath, P.J.; Farmer, A.; Cannon, S.B.; Woodward, J.; Kudapa, H.; Tuteja, R.; Kumar, A.; Bhanuprakash, A.; Mulaosmanovic, B.; Gujaria, N.; et al. Large-scale transcriptome analysis in chickpea (Cicer arietinum L.), an orphan legume crop of the semi-arid tropics of Asia and Africa. Plant Biotechnol. J. 2011, 9, 922-931. [CrossRef] [PubMed]

116. Hiremath, P.J.; Kumar, A.; Penmetsa, R.V.; Farmer, A.; Schlueter, J.A.; Chamarthi, S.K.; Whaley, A.M.; Carrasquilla-Garcia, N.; Gaur, P.M.; Upadhyaya, H.D.; et al. Large-scale development of cost-effective SNP marker assays for diversity assessment and genetic mapping in chickpea and comparative mapping in legumes. Plant Biotechnol. J. 2012, 10, 716-732. [CrossRef] [PubMed]

117. Gujaria, N.; Kumar, A.; Dauthal, P.; Dubey, A.; Hiremath, P.; Prakash, A.B.; Farmer, A.; Bhide, M.; Shah, T.; Gaur, P.M.; et al. Development and use of genic molecular markers (GMMs) for construction of a transcript map of chickpea (Cicer arietinum L.). Theor. Appl. Genet. 2011, 122, 1577-1589. [CrossRef] [PubMed]

118. Thudi, M.; Bohra, A.; Nayak, S.N.; Varghese, N.; Shah, T.M.; Penmetsa, R.V.; Thirunavukkarasu, N.; Gudipati, S.; Gaur, P.M.; Kulwal, P.L.; et al. Novel SSR Markers from BAC-End Sequences, DArT Arrays and a Comprehensive Genetic Map with 1,291 Marker Loci for Chickpea (Cicer arietinum L.). PLoS ONE 2011, 6, e27275. [CrossRef] [PubMed]

119. Ali, L.; Deokar, A.; Caballo, C.; Tar'an, B.; Gil, J.; Chen, W.; Millan, T.; Rubio, J. Fine mapping for double podding gene in chickpea. Theor. Appl. Genet. 2015, 129, 77-86. [CrossRef] [PubMed]

120. Jain, M.; Misra, G.; Patel, R.K.; Priya, P.; Jhanwar, S.; Khan, A.W.; Shah, N.; Singh, V.K.; Garg, R.; Jeena, G.; et al. A draft genome sequence of the pulse crop chickpea (Cicer arietinum L.). Plant J. 2013, 74, 715-729. [CrossRef] [PubMed]

121. Ali, L.; Azam, S.; Rubio, J.; Kudapa, H.; Madrid, E.; Varshney, R.K.; Castro, P.; Chen, W.; Gil, J.; Millan, T. Detection of a new QTL/gene for growth habit in chickpea CaLG1 using wide and narrow crosses. Euphytica 2015, 204, 473-485. [CrossRef]

122. Kumar, J.; Choudhary, A.K.; Solanki, R.K.; Pratap, A. Towards marker-assisted selection in pulses: A review. Plant Breed. 2011, 130, 297-313. [CrossRef]

123. Madrid, E.; Seoane, P.; Claros, M.G.; Barro, F.; Rubio, J.; Gil, J.; Millán, T. Genetic and physical mapping of the QTLAR3 controlling blight resistance in chickpea (Cicer arietinum L). Euphytica 2014, 198, 69-78. [CrossRef]

124. Poczai, P.; Varga, I.; Laos, M.; Cseh, A.; Bell, N.; Valkonen, J.P.T.; Hyvönen, J. Advances in plant gene-targeted and functional markers: A review. Plant Methods 2013, 9, 6. [CrossRef] [PubMed]

125. Collard, B.C.Y.; Mackill, D.J. Marker-assisted selection: An approach for precision plant breeding in the twenty-first century Marker-assisted selection: An approach for precision plant breeding in the twenty-first century. Phil. Trans. R. Soc. B 2008, 363, 557-572. [CrossRef] [PubMed] 
126. Varshney, R.K.; Mohan, S.M.; Gaur, P.M.; Chamarthi, S.K.; Singh, V.K.; Srinivasan, S.; Swapna, N.; Sharma, M.; Pande, S.; Varshney, R.K.; et al. Marker-Assisted Backcrossing to Introgress Resistance to Fusarium Wilt Race 1 and Ascochyta Blight in C 214, an Elite Cultivar of Chickpea. Plant Genome 2014. [CrossRef]

127. Taran, B.; Warkentin, T.D.; Vandenberg, A. Fast track genetic improvement of ascochyta blight resistance and double podding in chickpea by marker-assisted backcrossing. Theor. Appl. Genet. 2013, 126, 1639-1647. [CrossRef] [PubMed]

128. Iruela, M.; Rubio, J.; Barro, F.; Cubero, J.I.; Millán, T.; Gil, J. Detection of two quantitative trait loci for resistance to ascochyta blight in an intra-specific cross of chickpea (Cicer arietinum L.): Development of SCAR markers associated with resistance. Theor. Appl. Genet. 2006, 112, 278-287. [CrossRef] [PubMed]

129. Imtiaz, M.; Materne, M.; Hobson, K.; van Ginkel, M.; Malhotra, R.S. Molecular genetic diversity and linked resistance to ascochyta blight in Australian chickpea breeding materials and their wild relatives. Aust. J. Agric. Res. 2008, 59, 554-560. [CrossRef]

130. Madrid, E.; Chen, W.; Rajesh, P.N.; Castro, P.; Millán, T.; Gil, J. Allele-specific amplification for the detection of ascochyta blight resistance in chickpea. Euphytica 2013, 189, 183-190. [CrossRef]

131. Bouhadida, M.; Benjannet, R.; Madrid, E.; Amri, M.; Kharat, M. Efficiency of marker-assisted selection in detection of ascochyta blight resistance in Tunisian chickpea breeding lines. Phytopathol. Mediterr. 2013, 52, 202-211.

132. Castro, P.; Rubio, J.; Madrid, E.; Fernandez-Romero, M.D.; Millan, T.; Gil, J. Efficiency of marker-assisted selection for ascochyta blight in chickpea. J. Agric. Sci. 2013, 153, 56-67. [CrossRef]

133. Castro, P.; Pistón, F.; Madrid, E.; Millán, T.; Gil, J.; Rubio, J. Development of chickpea near-isogenic lines for fusarium wilt. Theor. Appl. Genet. 2010, 121, 1519-1526. [CrossRef] [PubMed]

134. Jendoubi, W.; Bouhadida, M.; Millan, T.; Kharrat, M.; Gil, J.; Rubio, J.; Madrid, E. Identification of the target region including the Foc 01 / foc 01 gene and development of near isogenic lines for resistance to Fusarium Wilt race 0 in chickpea. Euphytica 2016, 210, 119-133. [CrossRef]

(c) 2017 by the authors. Licensee MDPI, Basel, Switzerland. This article is an open access article distributed under the terms and conditions of the Creative Commons Attribution (CC BY) license (http:/ / creativecommons.org/licenses/by/4.0/). 